\title{
Water Uptake Patterns of Alfalfa under Winter Irrigation in Cold and Arid Grassland
}

\author{
Jiabin $\mathrm{Wu}{ }^{1,2,3}$, Heping $\mathrm{Li}^{2,3}$, Jianming Niu ${ }^{1, *}$, Tiejun Liu ${ }^{2,3}$, Hexiang Zheng ${ }^{2,3}$, Xiangtian Xu ${ }^{1}$ \\ and Shu Miao ${ }^{2,3}$ \\ 1 School of Ecology and Environment, Inner Mongolia University, Hohhot 010021, China; \\ mkswjb@163.com (J.W.); xuxt999@sina.com (X.X.) \\ 2 State Key Laboratory of Simulation and Regulation of Water Cycle in River Basin, China Institute of Water \\ Resources and Hydropower Research, Beijing 100038, China; mkslhp@163.com (H.L.); mksltj@126.com (T.L.); \\ zhenghexiang.29@163.com (H.Z.); miaoshu@vip.sina.com (S.M.) \\ 3 Institute of Water Resources for Pastoral Areas, China Institute of Water Resources and Hydropower Research, \\ Hohhot 010020, China \\ * Correspondence: jmniu2005@163.com; Tel.: +86-471-4616817
}

Received: 30 January 2020; Accepted: 7 April 2020; Published: 12 April 2020

\begin{abstract}
Crop reduction caused by cryogenesis and drought is a serious and global problem. The environmental stress caused by low temperature and drought during the overwintering stage of forage is the key factor leading to this low yield. In cold and arid grassland, winter irrigation can effectively alleviate the stress of alfalfa during overwintering, improve the survival rate of alfalfa, and significantly increase the yield. However, the water uptake patterns of alfalfa under winter irrigation are not clear, which are important to explore the mechanism of alleviating environmental stress by winter irrigation. In this research, the stable isotope compositions of all probable water sources and alfalfa xylem water were measured after winter irrigation. A graphical method was applied to identify the main soil layers with water uptake by the alfalfa roots. The contribution rate of available water sources to alfalfa xylem water was quantified by the MixSIAR (Bayesian isotope analysis mixing model in R) model. The results indicated that alfalfa absorbed soil water when the soil water content was high enough in the root layer when under high water volume freezing irrigation (irrigation in early winter when soil is freezing) but not under low and medium water volume freezing irrigation. Alfalfa gradually began to absorb soil water on the third day after thawing irrigation (irrigation in late winter when the soil is thawing) and showed different water uptake characteristics under low, medium, and high water volume. Thawing irrigation also accelerated the regeneration of alfalfa.
\end{abstract}

Keywords: water uptake patterns; winter irrigation; alfalfa; dual stable isotopes; MixSIAR

\section{Introduction}

Water is becoming increasingly scarce all over the world, particularly in arid and semi-arid districts. Abundant use of irrigation water promotes the development and application of efficient and water-saving irrigation systems [1]. Drip irrigation is a typical application of micro-irrigation technology and one of the common water-saving irrigation systems [2]. Drip irrigation systems deliver water to the entire field with almost no terrain impact [3,4], and reduce water loss caused by evaporation and leakage. In addition, the impact of drip irrigation on soil structure is minimal while eliminating surface runoff. These advantages make irrigation water use more efficient and promote sustainable agricultural development and soil and water conservation [5]. Therefore, drip irrigation has also been widely used in agriculture [6,7]. As the king of forage, alfalfa not only has abundant nutrients such as protein, energy, minerals, vitamins and other nutrients needed by livestock, but also has various 
economic and ecological functions such as soil and water conservation, vegetation restoration and soil fertility improvement [8]. About 70\% of Inner Mongolia is covered by grasslands [9], which is the largest grassland area in China and one of the most important animal husbandry provinces in China. The development of animal husbandry has accelerated the construction of cultivated grassland in Inner Mongolia. The area of grassland used for alfalfa cultivation is expanding. It is estimated that the area of forage grassland under water-saving irrigation will reach $453,000 \mathrm{hm}^{2}$ by 2020 [10]. At the same time, because Inner Mongolia is located just north of China, and the winter climate is cold and dry, people are constantly exploring how to effectively improve the overwintering rate of alfalfa and then promote a high yield of forage [11]. The practice has proved that winter irrigation can effectively alleviate cryogenic and drought stress on forage during winter. Judging from the water absorption of alfalfa in different root zones and soil layers under winter irrigation, this paper explores the mechanism of winter irrigation.

It is quite difficult, time-consuming, and impractical to determine the water sources and utilization strategies of plants using traditional methods (such as root excavation) [12]. The development of determination techniques enabled scientists to use stable isotopes as tracers to identify plant water sources [13]. However, these methods require two conditions to be met. Firstly, there must be significant differences in the isotopic composition of the various water sources [14,15]. Secondly, there must be no isotope fractionation in the process by which plant roots absorb and transport water [16]. Different hydrogen and oxygen isotopes combine to form water of different molecular weights. Because the thermodynamic properties of water molecules are related to the mass of its oxygen and hydrogen atoms, water has fractionated isotopes during processes including evaporation and coagulation. This results in significant differences in stable isotope contents in soil water at different depths, precipitation, groundwater, and xylem water [13]; therefore, the first condition is met. Many studies have proved that most plants do not undergo isotope fractionation when they uptake water from the roots and lift water from the roots $[17,18]$. Although some exceptions such as halophytic and xerophytic plants have challenged this assumption [19], there are no studies that show isotope fractionation in leguminous forage plants yet. Furthermore, it was also concluded that when oxygen and hydrogen isotopes are combined in the Bayesian inference method, the results are less sensitive to the fractionation of deuterium [20]. This satisfied the second condition. Therefore, by analyzing stable oxygen and hydrogen isotopes in plant xylem water and soil water from different depths, the proportion of plants using different water sources [21] and plant water use strategies can be determined [22].

Since the 1980s, with the improvement in mass spectrometry technology, stable isotope analysis techniques have been continuously applied and developed in plant water research [23-27]. Many applications of stable isotopes in plant water use models and strategies have been studied [22]. For example, the water use strategy of trees and shrubs in different habitats is as follows: if precipitation is the environmental water resource that is more important than stable deep soil water, the best plant phenotype will tend to maximize the use of precipitation. In contrast, if deep soil water matters more, the fittest plant phenotypes will tend to maximize their usage of this resource [26,28-31]. Researchers have verified that different functional plants use water in different ways by using stable oxygen and hydrogen isotopes [27,28,32-37]. The isotope tracer method is used to quantify the amount of plant water redistribution [25,37-40]. There are many applications in other studies and directions. Using stable oxygen and hydrogen isotopes for intensive studies of crop water uptake has a solid theoretical basis and is widely applied as a scientific tool.

The environmental stress caused by low temperature and drought during the overwintering of forage is the key factor leading to low yield from pasture [41]. Good water conditions in winter are conducive to the safe overwintering of forage [42]. When the soil water content is high, the surface temperature changes gradually; soil freezing and thawing is not very intense, and encountering sudden temperature rises and cooling or cryogenic stress is relatively light for alfalfa, and thus the overwinter survival rate is high [43]. The loss of agricultural and livestock production caused by cryogenic and drought disasters is a global problem. Low-temperature damage in the northern United 
States and western Canada, where alfalfa is planted in large areas, has led to severe losses in yield [44]. The northern China area has cold winters, with a dry and windy climate, which causes some crops to suffer from cryogenic and drought stress from winter to early spring. Mild cases include damaged branches and leaves, while the severe cases cause the death of the entire plant. Environmental stresses in early winter (including cold and dryness) and the following spring (including drought and cold damage caused by drastic changes in temperature) are the factors causing the death of winter crops [45]. In 2002, nearly $10,000 \mathrm{hm}^{2}$ of alfalfa in northern China suffered varying degrees of damage due to low temperatures [43]. In areas where the soil is often frozen in winter, watering before the soil freezes is called 'freezing irrigation'. After freezing, a frozen soil layer forms around the root system to keep the temperature in the root zone relatively stable and prevent sudden changes in the outside temperature from harming the plants. After thawing in early spring, timely watering is known as 'thawing irrigation', which can also play the same protective role of meeting crop needs for water in the turning green period [46], thereby improving the rate of returning green [47].

According to the literature, there are many studies on crop water uptake by using isotope analysis. Studies have mainly focused on water uptake during the growth and development of crops, but the water uptake of crops during the wintering period under winter irrigation, especially the water uptake patterns of perennial forage alfalfa, are very few, which is especially important to study the mechanism of winter irrigation to alleviate the cryogenic and drought stress of forage during wintering period. We use the MixSIAR (Bayesian isotope analysis mixing model in R) model, which explicitly considers the uncertainty in source values to estimate the water uptake of alfalfa in different root zones and soil layers under winter irrigation [48-51]. The purpose of this study is to: (1) identify whether freezing irrigation water is absorbed when alfalfa is about to enter the overwintering period after harvesting, and thawing irrigation water is absorbed before alfalfa returns to green in the next year; (2) quantify the water uptake ratio of alfalfa under different water volumes of winter irrigation; and (3) analyze alfalfa water uptake patterns under winter irrigation to provide a scientific basis for understanding the water use mechanism.

\section{Materials and Methods}

\subsection{Study Area}

This research was conducted in the Xilamuren grassland, $100 \mathrm{~km}$ north of Hohhot, China $\left(111^{\circ} 12^{\prime} 36^{\prime \prime} \mathrm{E}, 41^{\circ} 21^{\prime} 00^{\prime \prime} \mathrm{N}\right.$, elevation $\left.1600 \mathrm{~m}\right)$ from 2016 to 2017 . The study area was strongly influenced by the continental monsoon climate. It has cold and long winters, warm and short summers, strong variation between the two, and a large difference in day and night temperature. The average annual precipitation is $284 \mathrm{~mm}$, mostly concentrated from July to September. The average annual evaporation, annual average temperature, annual average sunshine hours, frost-free period, and annual average wind speed are $2305 \mathrm{~mm}, 2.5^{\circ} \mathrm{C}, 3100 \mathrm{~h}, 83$ days, and $4.5 \mathrm{~m} / \mathrm{s}$, respectively. The depth of groundwater was $15 \mathrm{~m}$. The root layer of alfalfa in the test area was concentrated at the depth of the $0-60 \mathrm{~cm}$ in the soil. The gravel content was more than $50 \%$ in the $60-100 \mathrm{~cm}$ soil layer. This layer of gravel restricted root growth in the study area to a depth of $60 \mathrm{~cm}$, which was verified by digging the root system. Table 1 shows the soil texture of the study area.

Table 1. Soil texture in the study area.

\begin{tabular}{cccc}
\hline Soil Depth $(\mathbf{c m})$ & Soil Texture & Bulk Density $\left(\mathrm{g} / \mathbf{c m}^{\mathbf{3}}\right)$ & $\theta_{\text {FC }}$ (Field Water Capacity, \%) \\
\hline $0-10$ & Loamy & 1.41 & 32.6 \\
$10-20$ & Loamy & 1.43 & 33.1 \\
$20-30$ & Sandy loam & 1.49 & 31.0 \\
$30-40$ & Sandy loam & 1.55 & 26.4 \\
$40-50$ & Sandy & 1.63 & 24.4 \\
$50-60$ & Sandy & 1.65 & 22.8 \\
$60-100$ & Gravel & - & - \\
\hline
\end{tabular}




\subsection{Experimental Design and Sample Collection}

The alfalfa variety used in the experiment was 'Zhungeer'. The planting was completed in the spring of 2014; $15 \mathrm{~kg} / \mathrm{ha}$ was sown in rows spaced at $30 \mathrm{~cm}$, at a sowing depth of $3 \mathrm{~cm}$. Many studies have shown that the most suitable cropping period of alfalfa in northern China is 6 years, and not more than 8 years [52-54]. After 6 years of alfalfa growth, the rotation of cereal and forage should be implemented to restore soil moisture and nutrients to ensure the sustainable use of land productivity [55]. Damage to the alfalfa plants by the natural environment and human factors cannot be avoided during alfalfa cropping years. Accumulation of damage to a certain extent results in a decline in alfalfa cropping years and alfalfa yield [56]. During the entire growth period, alfalfa that has been grown for 3 years exhibits rapid growth and strong regeneration ability. During the whole growth period, three-year alfalfa is fast-growing, has strong regeneration ability, and huge yield improving potential [52]. Therefore, the third year is the key year to ensure the success of alfalfa planting. In this study, alfalfa that was grown for 3 years was chosen as the research object to explore the water transport characteristics and application effects of the alfalfa field under winter irrigation.

The drip irrigation system used drip tubes spaced at $0.6 \mathrm{~m}$ with an outer diameter of $16 \mathrm{~mm}$, and the emitters spaced at $0.3 \mathrm{~m}$ with a flow rate of $2.5 \mathrm{~L} / \mathrm{h}$ (Figure 1 ). There were two winter irrigations. One was before the overwintering period, after alfalfa harvest when the soil underwent freezing and thawing during the nights and days, and alfalfa gradually entered a stable freezing period. This is the irrigation referred to as freezing irrigation. The other irrigation was carried out before the wintering period ended and before the plants entered the reviving stage. During this time, the soil was gradually thawing from the stable freezing period and this irrigation is called thawing irrigation. The specific time for the winter irrigation of alfalfa was based on the results of previous studies [45,57]. In this study, winter irrigation dates were determined to be 10 October 2016, and 7 May 2017, given the climatic conditions and field management experience. The irrigation level was controlled to low, medium, and high levels, which corresponded to $70-75 \%, 80-85 \%$ and $90-95 \%$ of field capacity (Table 2 ). The plot in which no winter irrigation was carried out was set as the control. A traditional field management technique was used to irrigate and fertilize alfalfa in the growing period, with the irrigation amount of $240 \mathrm{~mm}$, and the fertilizer application amount for compound fertilizer of $1.2 \mathrm{~kg} / \mathrm{m}^{2}$.

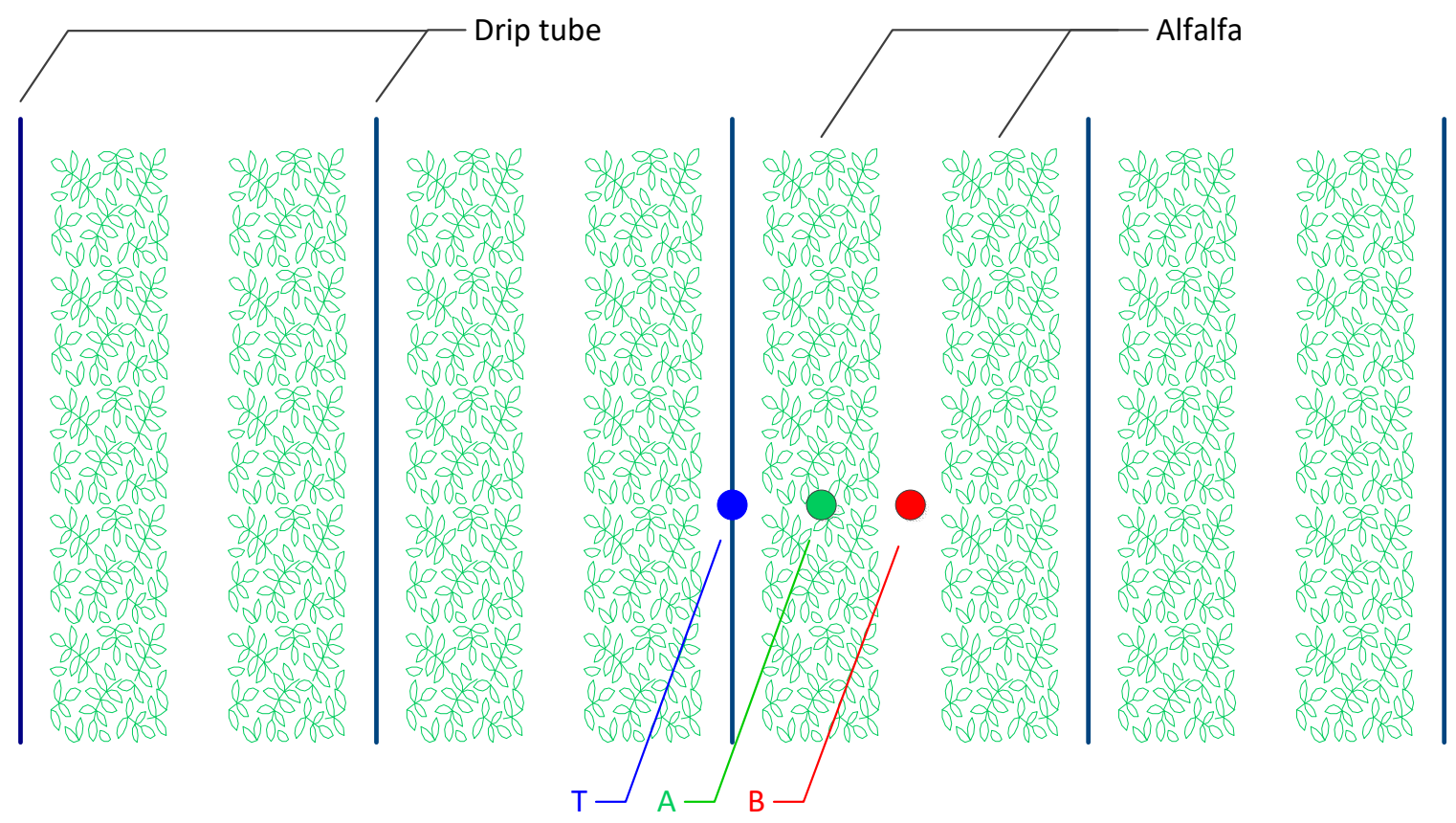

Figure 1. Sketch of the drip irrigation layout. Soil sampling locations: on the drip tube (T), among the alfalfa plants (A), and from the bare ground (B). 
Table 2. Winter irrigation schedule for alfalfa.

\begin{tabular}{|c|c|c|c|c|c|}
\hline $\begin{array}{l}\text { Winter } \\
\text { Irrigation }\end{array}$ & Irrigation Date & Irrigation Treatment & $\begin{array}{c}\text { Wetting } \\
\text { Depth }(\mathrm{cm})\end{array}$ & $\begin{array}{c}\text { Irrigation } \\
\text { Amount (mm) }\end{array}$ & $\begin{array}{l}\text { Threshold of Soil } \\
\text { Moisture } \theta_{\mathrm{FC}}(\%)\end{array}$ \\
\hline \multirow{4}{*}{$\begin{array}{l}\text { Freezing } \\
\text { irrigation }\end{array}$} & \multirow{4}{*}{10 October 2016} & No & No & 0.0 & Natural \\
\hline & & Low water volume & 60 & 6.8 & $70-75$ \\
\hline & & Medium water volume & 60 & 23.1 & $80-85$ \\
\hline & & High water volume & 60 & 39.7 & $90-95$ \\
\hline \multirow{4}{*}{$\begin{array}{l}\text { Thawing } \\
\text { irrigation }\end{array}$} & \multirow{4}{*}{$\begin{array}{l}7 \text { May } 7 \\
2017\end{array}$} & No & No & 0.0 & Natural \\
\hline & & Low water volume & 60 & 22.6 & $70-75$ \\
\hline & & Medium water volume & 60 & 40.3 & $80-85$ \\
\hline & & High water volume & 60 & 54.2 & $90-95$ \\
\hline
\end{tabular}

Note: natural means alfalfa field without winter irrigation.

Because of the soil texture, the root layer of alfalfa in the study area is restricted at the depth of $60 \mathrm{~cm}$. So, the irrigation depth is determined to be $60 \mathrm{~cm}$. We measure the soil moisture in different layers between $0-60 \mathrm{~cm}$ before irrigation to calculate the irrigation amount. It is generally believed that soil moisture tends to stabilize within 5 days after winter irrigation under drip irrigation [58,59]. Therefore, the sampling times were the first, second, third, and fifth days after winter irrigation. Drip irrigation has a unique way of diffusing water, and soil water in the field will also show the characteristics of strip distribution after winter irrigation. Therefore, soil samples were collected at three locations: in the drip tape irrigation zone, in the alfalfa zone, and from the bare ground between alfalfa strips. The three locations are shown in Figure 1.

\subsection{Sample Collection and Isotopic Analyses}

After freezing and thawing irrigation, the oxygen and hydrogen isotopic abundances of all probable water sources and alfalfa xylem water were measured. A graphical method was applied to preliminarily judge the water uptake of the alfalfa root and its main soil layers. The contribution rate of the considered water sources to alfalfa xylem water was quantified by the MixSIAR model.

The xylem water and soil water extracted by the traditional method of cryogenic vacuum distillation can contain organic contamination [60], which may interfere with the iris's spectral signal and cause errors in oxygen and hydrogen isotope measurements [61]. There were two sample treatment methods and a software detection method used to eliminate the impact of organic contamination on the results. Each water sample was filtered by a needle filter with a diameter of $0.22 \mu \mathrm{m}$ before being tested by the instrument to remove impurities and large particles of organic matter in the water sample. Secondly, the Micro-Combustion Module ${ }^{\mathrm{TM}}$ of the system was opened when the instrument measured the soil water and alfalfa xylem water, which can effectively eliminate the spectral interference of common organic contamination, including alcohols, terpenes, and volatiles. Finally, proprietary software, called ChemCorrect ${ }^{\mathrm{TM}}$, was used to carry out spectral analysis on the isotopic test results of water samples, mark the content of organic pollutants in water samples, and mark different pollution levels, which helped us judge whether the data was reliable before proceeding to a full analytical method. In this way, the reliability of the data quality can be guaranteed.

\subsubsection{Alfalfa Xylem Water}

According to the steady-state hypothesis, samples were taken at noon on sunny days to prevent isotope fractionation due to transpiration. Healthy and mature alfalfa plants were cut using scissors, and sampling occurred three times per plant. The stalks of plants without chlorophyll were cut at a depth of $5 \mathrm{~cm}$ from the surface and immediately placed into clean glass bottles $(20 \mathrm{~mL})$, sealed, frozen and stored at $-4{ }^{\circ} \mathrm{C}$ until xylem water was extracted with a vacuum extraction system (SW-VE, Techno solutions, China). The pressure was set to $1.0 \mathrm{kPa}$, the extraction temperature was set to $95^{\circ} \mathrm{C}$, the cooling method was liquid nitrogen cooling, and the extraction time was $3 \mathrm{~h}$. 


\subsubsection{Soil Water}

The soil samples were collected simultaneously with alfalfa samples; the sampling positions are shown in Figure 1. Soil samples were collected with a soil auger (the length and diameter are $100 \mathrm{~cm}$ and $10 \mathrm{~cm}$, respectively) per $10 \mathrm{~cm}$ within $60 \mathrm{~cm}$ depth in each point, and every soil layer was repeated three times. Soil samples were placed and sealed into glass bottles and stored at $-4{ }^{\circ} \mathrm{C}$ until isotopic analysis was performed. The soil water was extracted by the vacuum extraction method, the vacuum pressure was set to $1.0 \mathrm{kPa}$, the extraction temperature was set to $95^{\circ} \mathrm{C}$, the extraction time was $2.5 \mathrm{~h}$, and the cooling method was liquid nitrogen cooling.

\subsubsection{Irrigation Water and Precipitation}

Precipitation and irrigation water were collected and filtered off impurities using $0.22 \mu \mathrm{m}$ filter paper. To avoid evaporation fractionation, the water samples were wrapped with parafilm and frozen until the isotopic analysis was performed. The stable isotopes of water samples were analyzed using an analyzer called L2014-I (Picarro, Inc. Santa Clara, CA, USA), and the typical accuracy of oxygen isotopes $\left(\delta^{18} \mathrm{O}\right)$ is $0.011 \%$, and hydrogen isotopes $(\delta \mathrm{D})$ is $0.038 \%$. The composition of $\delta^{18} \mathrm{O}$ and $\delta \mathrm{D}$ were calculated according to the Vienna Standard Mean Ocean Water guidelines.

\subsection{Overwintering Rate and Forage Yield}

Winter irrigation is helpful for alfalfa to survive safely during the wintering period. The intuitive data should be expressed in the overwintering rate and yield of alfalfa. The overwintering rates of alfalfa under different winter irrigation treatments were sampled and calculated as follows. Three $1 \mathrm{~m}^{2}$ plots were randomly selected for each treatment, and the number of alfalfa plants in the plot was counted before and after overwintering. The soil around the plant was removed with a spade to expose the root and stem, and the plants were separated from each other for easy counting. After identifying the number of plants, markers were placed. In the following year, the number of surviving plants was determined and the rate of overwintering was calculated. The calculation formula is as follows:

$$
S=(F / Y) \times 100
$$

where $S$ is the overwintering rate of alfalfa (\%), $F$ is the number of alfalfa survivors, and $Y$ is the number of alfalfa plants before overwintering.

The experimental field adopted the local alfalfa mowing system, and harvested twice a year in early July and mid-September. During each harvest season, plant samples were randomly selected from a single row in a $3 \mathrm{~m}$ area and repeated three times for each plot. The fresh weight and dry-to-fresh ratio of each sample were measured.

\subsection{Data Analysis}

The groundwater table is below $15 \mathrm{~m}$, which is deep enough that alfalfa cannot directly absorb groundwater. Therefore, groundwater cannot be considered as one of the potential water sources. Moreover, there was no surface runoff due to the use of the efficient and water-saving drip irrigation. The water absorbed by alfalfa mainly comes from soil water at different depths, which is a mixture of irrigation water, previous soil water, and precipitation. Thus, the main potential source for alfalfa water uptake was soil water from different depths.

The water uptake depths of alfalfa were preliminarily judged by a graphical method. The graphical method used determines the main water-absorbing layer by comparing the stable isotope distributions of xylem water and soil water. According to the output of the graphical method, the stable isotope of xylem water is a vertical line, while the stable isotope distribution of soil water is a curve. The depths at which the two intersect are considered to be the main water-absorbing layers of the alfalfa root system $[62,63]$. 
The uptake proportions of water sources were estimated by the Bayesian isotope mixing model (MixSIAR v3.1) [64]. The uncertainty in sources and discrimination factors are explicitly considered in MixSIAR to ameliorate simpler linear mixing models [51,64]. In this study, the mean and standard deviations (SD) of isotope values from various soil horizons $(0-10 \mathrm{~cm}, 10-20 \mathrm{~cm}, 20-30 \mathrm{~cm}$, $30-40 \mathrm{~cm}, 40-50 \mathrm{~cm}, 50-60 \mathrm{~cm})$ and corresponding xylem water were used as inputs for MixSIAR. The discrimination factor between sources and xylem water are usually set to zero when MixSIAR is applied, and this study did the same $[19,20,65]$. The model predictions were presented as mean values. In order to facilitate subsequent comparison and analysis, three larger layers $(0-20 \mathrm{~cm}, 20-40 \mathrm{~cm}$, $40-60 \mathrm{~cm}$ ) were combined from 6 different depth of soil layers [66].

\subsection{Statistical Analysis}

Microsoft Excel 2013 and SPSS 19.0 were used to sort and analyze the research data, and to compile the figures and tables of this paper.

\section{Results}

\subsection{Oxygen and Hydrogen Isotopic Values of Water Samples}

There were highly linear relationships between $\delta^{18} \mathrm{O}$ and $\delta \mathrm{D}$ in water samples, as shown in Figure 2. For local precipitation, the linear relationship between $\delta^{18} \mathrm{O}$ and $\delta \mathrm{D}$ is $\delta \mathrm{D}=7.21 \delta^{18} \mathrm{O}+9.14$, which is close to the global atmospheric precipitation line $\left(\delta \mathrm{D}=8 \delta^{18} \mathrm{O}+10\right)$ [67]. The $\delta^{18} \mathrm{O}$ and $\delta \mathrm{D}$ values of stem water ranged from -12.94 to $5.73 \%$ and -102.49 to $-20.41 \%$, respectively. The $\delta^{18} \mathrm{O}$ and $\delta \mathrm{D}$ values in xylem water were $-11.00 \%$ ond $-92.37 \%$. The $\delta^{18} \mathrm{O}$ and $\delta \mathrm{D}$ values of groundwater ranged from -13.56 to $-6.68 \%$ and -106.57 to $-62.02 \%$, respectively. Oxygen and hydrogen isotopes have a significant linear correlation in all water samples, and the linear expressions of oxygen and hydrogen isotopes of different water samples are labeled in Figure 2.

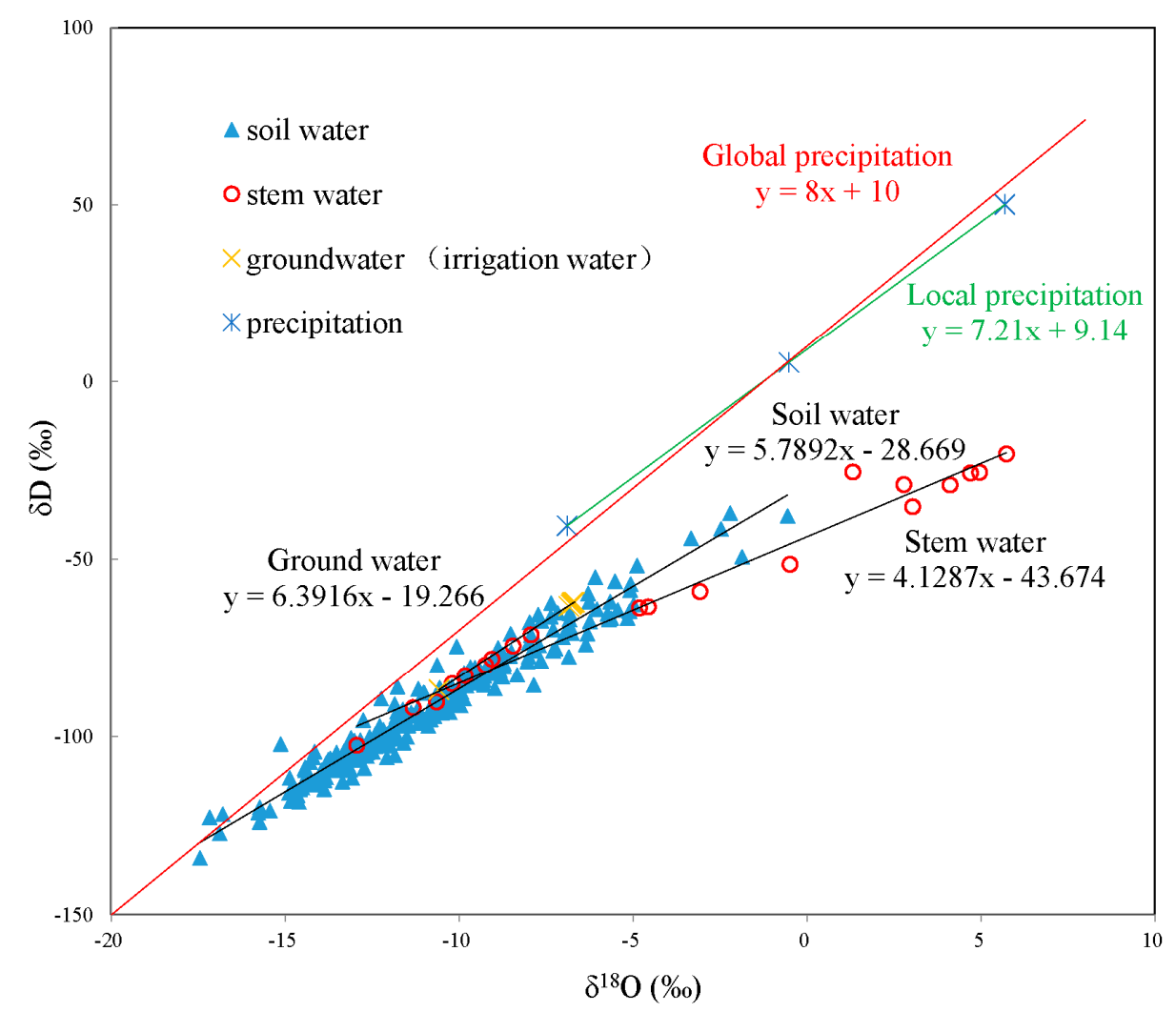

Figure 2. Relationship between oxygen isotopes $\left(\delta^{18} \mathrm{O}\right)$ and hydrogen isotopes $(\delta \mathrm{D})$ of different water samples. 


\subsection{Distribution of Stable Isotopes in the Root Zone after Freezing Irrigation}

The graphical method was applied to preliminarily estimate the depths of water uptake [14]. If the soil water and xylem water have isotopic intersections at some depths, it indicates that the main source of water is from the particular soil water layer [68]. The dynamic distribution and intersection of stable isotopes of soil water and xylem water after freezing irrigation are shown in Figure 3.

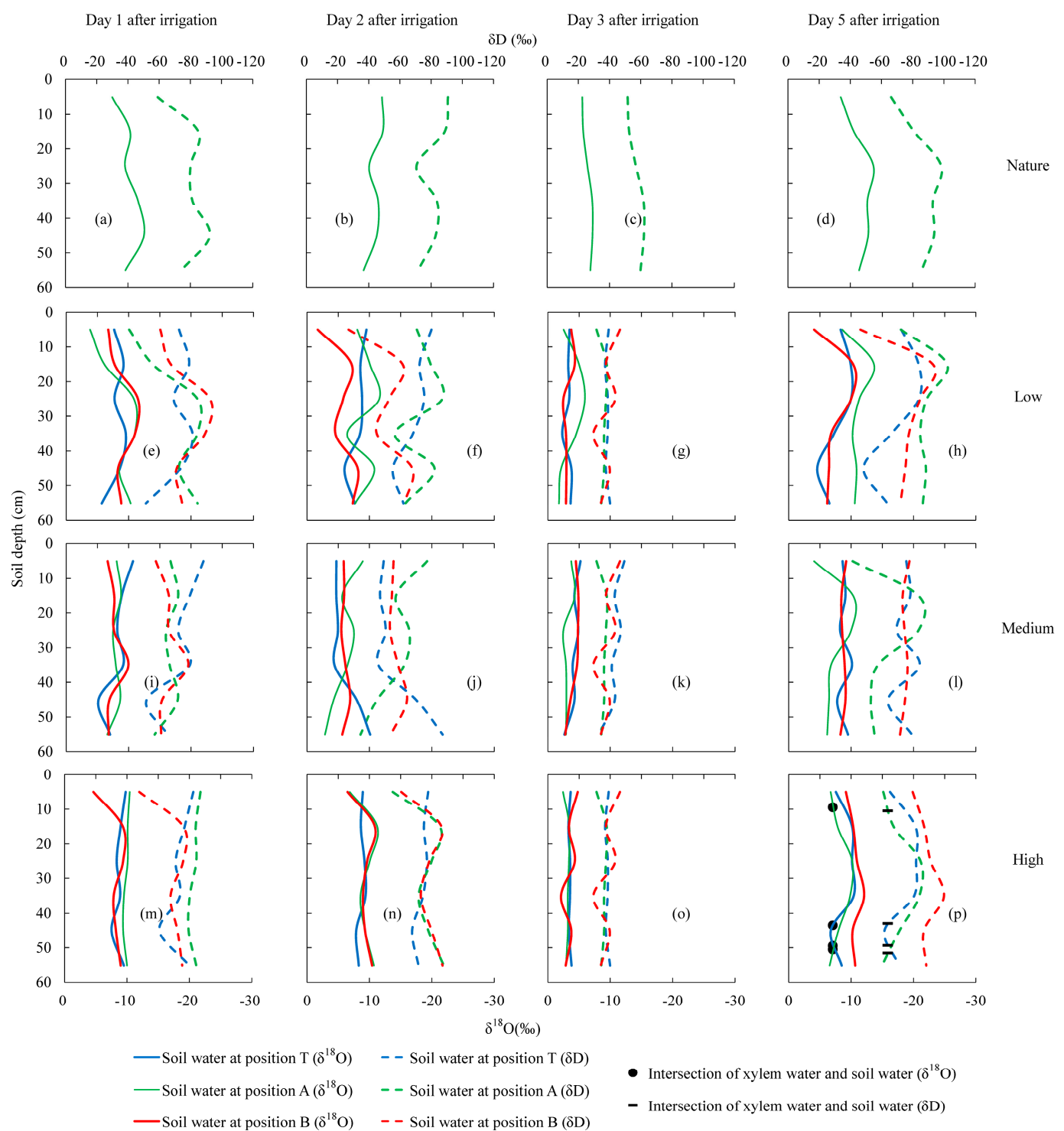

Figure 3. Dynamic distribution of $\delta^{18} \mathrm{O}$ and $\delta \mathrm{D}$ in xylem water and soil water after freezing irrigation. T: drip tube, A: alfalfa rows, B: bare ground. The plot numbers (a-p) correspond to the sample processing and sampling time (i.e., plot (e) corresponds to day 1 after irrigation under low water volume irrigation). The sampling dates were from October 11 to 15, 2016 (early winter). Freezing irrigation was carried out on October 10, 2016, and natural, low, medium and high water volume irrigation treatments were adopted with irrigation quotas of $0.0 \mathrm{~mm}, 6.8 \mathrm{~mm}, 23.1 \mathrm{~mm}$, and $39.7 \mathrm{~mm}$, respectively.

Figure 3 reflects the variation and distribution profile of the $\delta^{18} \mathrm{O}$ and $\delta \mathrm{D}$ values of xylem water and soil water in the root layer after freezing irrigation. Soil water $\delta^{18} \mathrm{O}$ and $\delta \mathrm{D}$ underwent pronounced changes after freezing irrigation. Although the stable oxygen and hydrogen isotopes are distributed in different regions, there was a very high similarity in how regular their variations were due to the high linear correlation between them. Figure 3 shows that on the third day after freezing irrigation, the distribution of the $\delta^{18} \mathrm{O}$ and $\delta \mathrm{D}$ profiles of soil water at T, A, and B tends to be uniform (Figure $\left.3 \mathrm{~g}, \mathrm{k}, \mathrm{o}\right)$, 
indicating that the soil water underwent a series of transport process, and that drip irrigation water evenly wetted the root layer of the alfalfa and was distributed therein.

\subsection{Distribution of Stable Isotopes in the Root Zone after Thawing Irrigation}

The thawing irrigation time is before greening at the end of winter. By this time, the freezing irrigation from the previous year has passed a long wintering period of up to seven months. The root layer soil was quite dry; therefore, the thawing irrigation alleviated the low temperature and drought stress faced by alfalfa and thereby improved the overwinter survival rate. Thawing irrigation was also carried out at low, medium and high irrigation levels, and the natural condition was taken as a control check. The variation and distribution profile for the $\delta^{18} \mathrm{O}$ and $\delta \mathrm{D}$ of soil water, and intersections with xylem water after thawing irrigation, are shown in Figure 4.

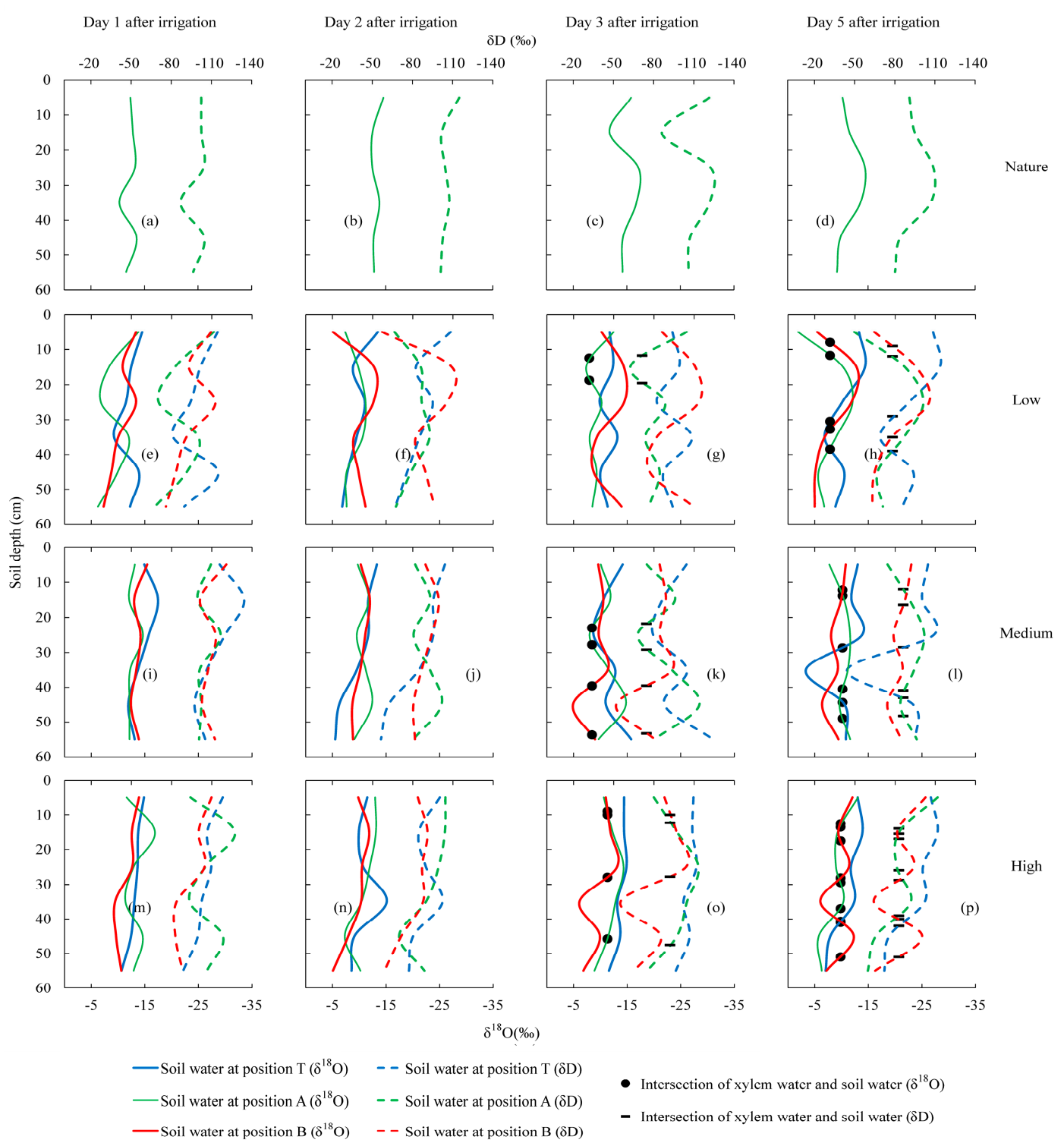

Figure 4. Dynamic distribution of $\delta^{18} \mathrm{O}$ and $\delta \mathrm{D}$ in soil water and xylem water after thawing irrigation. T: drip tube, A: alfalfa rows, B: bare ground. The plot numbers (a-p) correspond to the sample processing and sampling time (i.e., plot (e) corresponds day 1 after irrigation under low water volume irrigation). The sampling dates were 8-12 May 2017 (late winter). Thawing irrigation was carried out on 7 May 7 2017, and nature, low, medium and high water volume irrigation treatments were adopted with irrigation quotas of $0.0 \mathrm{~mm}, 22.6 \mathrm{~mm}, 29 \mathrm{~mm}, 40.3 \mathrm{~mm}$, and $54.2 \mathrm{~mm}$, respectively. 


\subsection{Overwintering Rate and Forage Yield under Winter Irrigation}

The alfalfa overwintering rate and hay yield under different winter irrigation treatments were measured, and the results are listed in Table 3.

Table 3. Overwintering rate and hay yield of alfalfa.

\begin{tabular}{ccccc}
\hline Winter Irrigation & Natural & $\mathbf{L}$ & $\mathbf{M}$ & $\mathbf{H}$ \\
\hline Overwintering rate (\%) & $45.75 \mathrm{c}$ & $53.24 \mathrm{c}$ & $65.75 \mathrm{~b}$ & $80.46 \mathrm{a}$ \\
Yield of first harvest (hay, kg/ha) & $1875 \mathrm{~d}$ & $2640 \mathrm{c}$ & $3345 \mathrm{~b}$ & $4035 \mathrm{a}$ \\
Yield of second harvest (hay, kg/ha) & $889 \mathrm{c}$ & $1033 \mathrm{~b}$ & $1156 \mathrm{a}$ & $1227 \mathrm{a}$ \\
\hline
\end{tabular}

Notes: $\mathrm{L}, \mathrm{M}$, and $\mathrm{H}$ are the winter irrigation treatments with different water volumes. $\mathrm{L}$ : low water volume; M: medium water volume; $\mathrm{H}$ : high water volume. The different letters indicate the statistical significance of $\alpha=0.05$ in the same row among different treatments.

Under the stress of low temperature and drought in winter, the overwintering rate of alfalfa under natural conditions is less than $50 \%$. With reasonable winter irrigation treatment, the overwintering rate of alfalfa can reach $80 \%$. It can be seen that through rational winter irrigation, the overwintering rate of alfalfa can be increased by more than $30 \%$. From the forage yield point of view, the hay yield of alfalfa under winter irrigation can be significantly increased compared with the control group. The results show that winter irrigation significantly increased the overwintering rate and hay yield of alfalfa. The overwintering rate and hay yield of alfalfa increased with the increase of water amount of winter irrigation.

\section{Discussion}

\subsection{Characteristics of Water Uptake after Freezing Irrigation}

According to the graphical method used, under the four irrigation treatments (natural, which refers to the control treatment without winter irrigation, low, medium, and high), there was no isotopic interaction between soil water and xylem water (except the fifth day after high water volume freezing irrigation (Figure 4p)), indicating that the alfalfa only absorbed soil water under high water volume freezing irrigation. The oxygen and hydrogen isotope values of soil water varied greatly, which was due to the enrichment caused by soil evaporation on the one hand [69], and the stable isotope of soil water decreased after the soil absorbed irrigation water on the other hand.

If the soil water and xylem water have isotopic intersections at some depths, it indicates that the main source of water is from the particular soil water layer [67]. On the fifth day after freezing irrigation at the high water volume, there were four pairs of isotopic intersections between soil water and xylem water. For vertical water uptake, soil depth was taken as a reference index. The isotopic intersections were concentrated at the depths of $10 \mathrm{~cm}$ and $50 \mathrm{~cm}$, indicating that the soil water at these two depths was the main source of xylem water. The horizontal water uptake refers to the stem water uptake of alfalfa from different soil zones horizontally, specifically referring to positions A, T, and B. The three positions were, from left to right, the irrigation drip tube, the alfalfa rows, and the bare ground between the alfalfa rows (Figure 2, positions T, A, and B, respectively). In the main absorbent soil layers at depths of $10 \mathrm{~cm}$ and $50 \mathrm{~cm}$, the isotopic intersections between soil water and xylem water at position $\mathrm{A}$ indicated that shallow and deep soil water might be taken up by alfalfa from both layers of soil in the alfalfa planting belt area. At $50 \mathrm{~cm}$, xylem water intersected with the soil water at position $\mathrm{T}$ in the isotope curves, indicating that the deep layer of the alfalfa root also absorbed soil water from the side of the drip irrigation tube. There was no isotopic intersection between soil water and xylem water in the bare ground between alfalfa rows, which might have been due to their soil water content being relatively low.

The results showed that alfalfa could absorb soil water only when the soil water content was high enough in the root layer under high water volume freezing irrigation. Low and medium water 
volume freezing irrigation only caused changes in soil water content, but alfalfa does not directly absorb soil water.

\subsection{Estimating the Source Contribution to Xylem Water after Freezing Irrigation}

Analysis of stable isotopes has become an important tool for researchers because it can be used to answer many environmental questions, such as calculating plant water use from soil horizons, determining diet composition, and analyzing carbon sources for ecosystem respiration. MixSIAR helped us to create and run Bayesian mixing models to analyze the proportions of source contributions to alfalfa water uptake [64].

As noted above, the graphical method showed that alfalfa absorbed soil water only on the fifth day after high water volume freezing irrigation. The stable isotope profiles showed that soil water at positions $\mathrm{T}$ and $\mathrm{A}$ were absorbed by alfalfa, but that at position $\mathrm{B}$ was not. Therefore, the contributions of soil water to alfalfa water uptake at different depths at positions $\mathrm{T}$ and $\mathrm{A}$ were analyzed by using MixSIAR, as shown in Figure 6. The contribution rate of the soil water at a depth of 40-50 cm layer at position $\mathrm{T}$ to alfalfa xylem water reached $43.2 \pm 5.94 \%$ (mean \pm standard deviation (SD)), while the contribution rate of the other soil layers was less than 15\% (Figure 5a). This is consistent with the results of the previous application of the graphical method, which showed that the $40-50 \mathrm{~cm}$ soil layer is the main absorbent layer for alfalfa on the side of the drip irrigation tube. At position A, alfalfa had three main water-absorbent layers: 0-10 cm, 40-50 cm, and 50-60 cm. Each of these contributes more than $20 \%$ to xylem water (Figure $5 \mathrm{~b}$ ). This was consistent with the analysis results first obtained using the previous graphical method. The contribution rates of the three main water-absorbent layers are $21 \pm 5.04 \%, 20.9 \pm 4.97 \%$, and $27.3 \pm 5.45 \%$ respectively. The three soil layers with the highest average contribution rate for xylem water, from high to low, were $40-50 \mathrm{~cm}, 50-60 \mathrm{~cm}$, and 0-10 cm. The total contribution rate of these three soil layers was $70 \%$, while the contribution rate of the other three soil layers $(10-20 \mathrm{~cm}, 20-30 \mathrm{~cm}$, and $30-40 \mathrm{~cm}$ ) was each about 10\% (Figure $5 \mathrm{c}$ ).

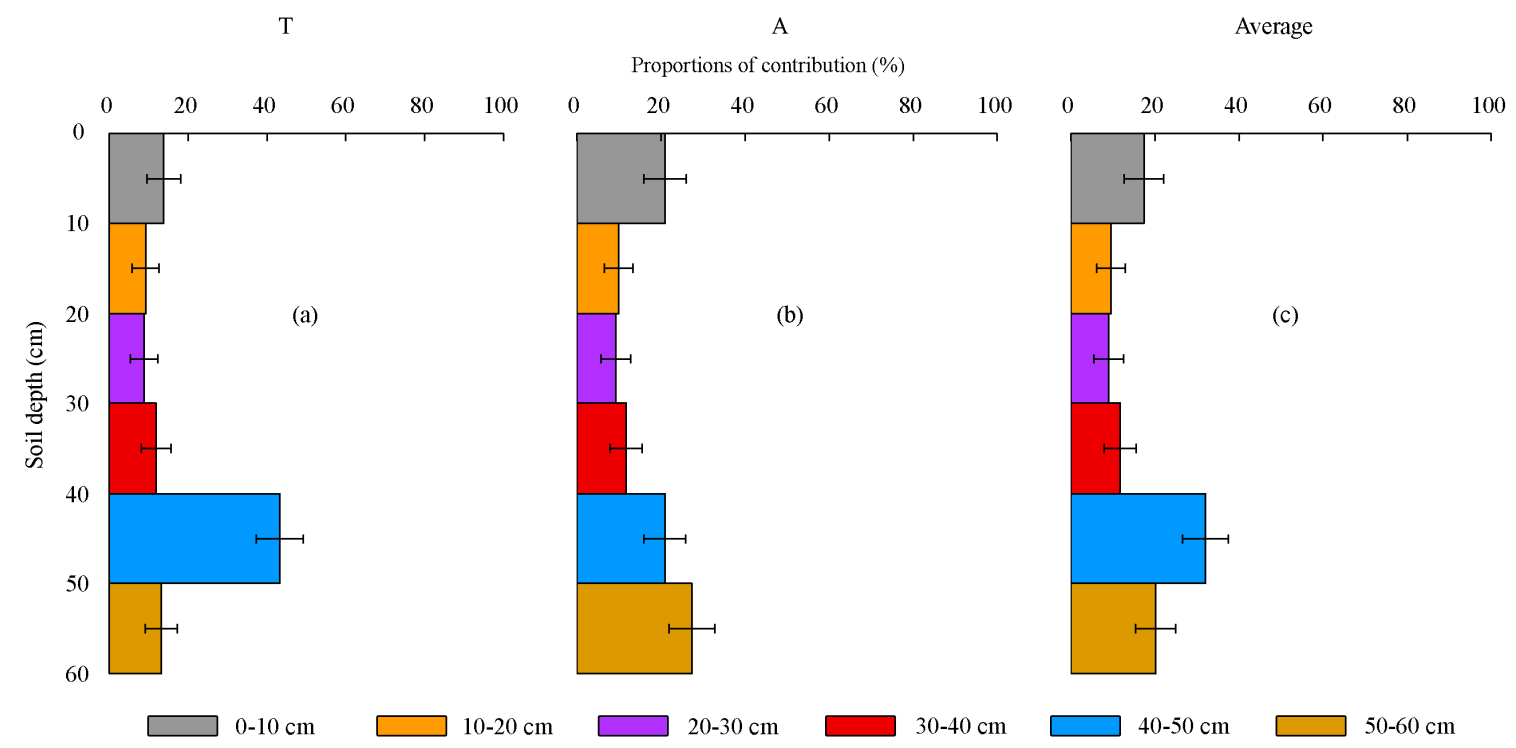

Figure 5. Contributions of soil water to alfalfa water uptake on the fifth day (15 October 2016) after freezing irrigation at high water volume. $(\mathbf{a}-\mathbf{c})$ are figures in the case of T, A and average respectively. $\mathrm{T}$ : the position of drip tube, A: the position of alfalfa rows, Average: average contribution of soil water at $\mathrm{T}$ and $\mathrm{A}$.

The freezing irrigation was carried out before the overwintering stage but after the alfalfa was mowed. This research showed that alfalfa absorbed water only when freezing irrigation is at high water volumes and the main water-absorbing layers were shallow and deep soil layers of the root zone. 
However, the alfalfa did not absorb soil water directly under low and medium water volumes freezing irrigation conditions. The overwintering rates for alfalfa were $46.76 \%, 62.60 \%, 76.49 \%$, and $84.64 \%$ under the natural, low, medium, and high water volumes under freezing irrigation conditions. The overwintering rates for alfalfa increased with the increase in irrigation water. The reason for this may be due to the increment of water content and heat capacity of the root layer soil caused by freezing irrigation. This prevented drastic changes in temperature in the alfalfa root zone before winter and provided good environmental conditions to acclimatize alfalfa to cold conditions, thus improving the alfalfa overwintering rate [70-74]. Also, repeated thawing and freezing of soil and the days and nights after freezing irrigation played a role in loosening the soil and improving alfalfa habitat conditions.

\subsection{Characteristics of Water Uptake after Thawing Irrigation}

After thawing irrigation, the xylem water and soil water underwent dynamic changes in $\delta^{18} \mathrm{O}$ and $\delta \mathrm{D}$. In the control check, under natural treatment, there was no overlap between the $\delta^{18} \mathrm{O}$ and $\delta \mathrm{D}$ of soil water and xylem water (Figure $4 a-d$ ) during the observation period (8-12 May 2017). This means that the alfalfa did not take up water from soil in the natural treatment and the alfalfa still remained dormant.

From the third day after the thawing irrigation, the number of intersections between soil water and xylem water for $\delta^{18} \mathrm{O}$ and $\delta \mathrm{D}$ increased. With the increase of thawing irrigation quota, the number of intersections and the corresponding soil layers increased (Figure $4 \mathrm{~g}, \mathrm{~h}, \mathrm{k}, \mathrm{l}, \mathrm{o}, \mathrm{p}$ ). This indicates that thawing irrigation revived the alfalfa from a dormant state. The number of water uptake points and water uptake layers also increased with the increase in irrigation water.

Furthermore, thawing irrigation alleviated the environmental stress on the alfalfa during the turning green period and caused dormancy to end earlier. Thus, thawing irrigation can also improve the survival rate and yield of alfalfa [43]. However, in actual production conditions, alfalfa may suffer from late spring coldness if the spring temperature varies greatly and the period of returning green comes earlier. Therefore, timing is very important for thawing irrigation; it is believed that the optimum time for thawing irrigation is when the average daily minimum temperature is above $-4{ }^{\circ} \mathrm{C}$ in northern China [43].

\subsection{Estimating the Source Contribution to Xylem Water after Thawing Irrigation}

For $\delta^{18} \mathrm{O}$ and $\delta \mathrm{D}$, the soil layers have no significant differences between 0-60 $\mathrm{cm}(0-10 \mathrm{~cm}$, $10-20 \mathrm{~cm}, 20-30 \mathrm{~cm}, 30-40 \mathrm{~cm}, 40-50 \mathrm{~cm}$, and $50-60 \mathrm{~cm})(p>0.05)$. Therefore, the $\delta^{18} \mathrm{O}$ and $\delta \mathrm{D}$ values of the root zone soil were divided into three layers of 0-20 cm, 20-40 cm, and 40-60 cm, which represent the shallow, middle, and deep layers, respectively. The relative contribution of soil water from different soil layers and different points to alfalfa water uptake was estimated by MixSIAR, as shown in Figure 6.

If the proportion of alfalfa absorbing soil water at different depths is regarded as vertical analysis, then the contribution rate of different positions in a soil layer ( $T, A, B$, Figure 1) to alfalfa water uptake can be regarded as horizontal analysis. The water uptake patterns of alfalfa after thawing irrigation showed different characteristics in both directions. When thawing irrigation had a low water volume, the main absorbent layer at positions $\mathrm{T}$ and $\mathrm{B}$ was middle soil, and their relative contribution rates were $62.5 \pm 9.12 \%$ and $51.3 \pm 8.49 \%$ (mean $\pm \mathrm{SD}$ ), respectively. The main uptake layer at position $\mathrm{A}$ is deep soil, and the relative contribution rate is $69.8+10.82 \%$ (Figure $6 \mathrm{a}$ ). This indicated that alfalfa water uptake is concentrated in middle and deep soil under low water volume thawing irrigation conditions. In the case of the medium irrigation quota, the proportions of soil water contributions to alfalfa water uptake were similar for different soil layers and points (Figure 6b). The contribution rate ranged from $27.3 \%$ to $39.6 \%$ and the range in variation was only $12.3 \%$. The results showed that alfalfa could uptake soil water at different points and depths under medium water volume thawing irrigation conditions. Under high water volume thawing irrigation conditions, soil water at intermediate depths had the highest contribution rate. The contribution rates of soil water between $20-40 \mathrm{~cm}$ depth at positions $\mathrm{T}, \mathrm{A}$, and B were $41.2 \pm 8.91 \%, 57.8 \pm 10.32 \%$, and $44.5 \pm 9.66 \%$, respectively. The contribution 
rates of soil water to xylem water at different depths and points were all greater than $20 \%$ (Figure $6 \mathrm{c}$ ). This indicated that the soil water was absorbed at all depths and that the middle soil layer was the main absorbent layer at high water volume thawing irrigation conditions.
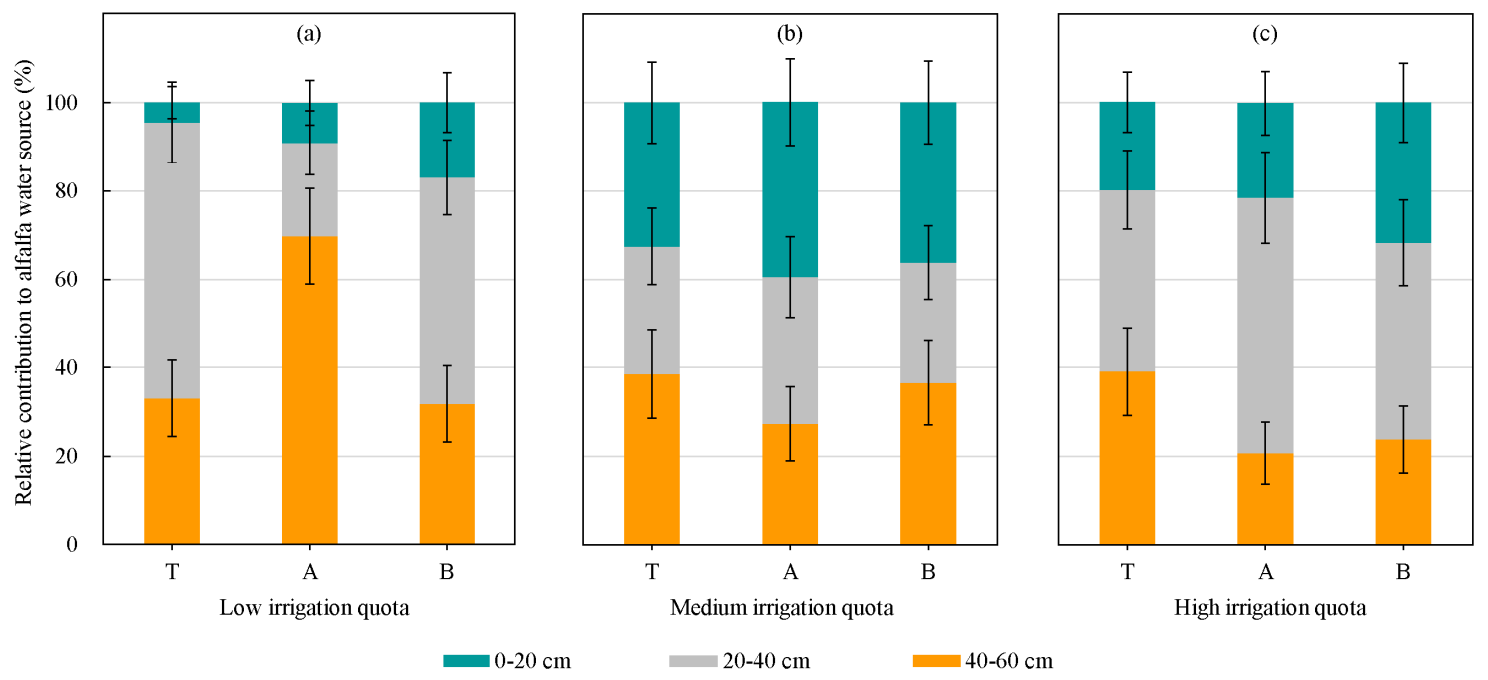

Figure 6. Contribution of soil water to xylem water after thawing irrigation. $(\mathbf{a}-\mathbf{c})$ are figures in the case of low irrigation quota, medium irrigation quota and high irrigation quota respectively. T: drip tube, A: alfalfa rows, B: bare ground.

Combining the results of the graphical method and the MixSIAR model produces some useful information. For example, from the third day after thawing irrigation, with the diffusion of irrigation water in the soil and the passage of time, alfalfa began to absorb soil water and absorbent soil layers gradually increased, indicating that thawing irrigation was conducive to restoring the vitality of alfalfa roots. Furthermore, thawing irrigation promoted alfalfa greening ahead of time compared to natural treatment. The water uptake patterns of alfalfa showed different characteristics when the quantities of thawing irrigation water varied. Alfalfa tends to uptake water from deep and middle soil layers mainly under thawing irrigation when the irrigation quota is low. Under medium and high water volume thawing irrigation conditions, alfalfa utilized soil water in both the horizontal and vertical directions.

According to the overwintering rate and forage yield under winter irrigation, on the one hand, winter irrigation can effectively improve the overwintering rate and vigor of alfalfa, which has a greater impact on the hay yield at the first cut of alfalfa [56]. On the other hand, three-year alfalfa is in the growth period with the most productive potential [52]. Winter irrigation undoubtedly contributed to the release of the production potential of alfalfa.

\section{Conclusions}

Stable isotope analysis of oxygen and hydrogen is a suitable methodology for the study of plant water use, water conversion, water availability, and water use efficiency. In plant water uptake studies, the combination of the graphical method with the MixSIAR model to analyze stable isotopes utilizes the advantages of both methods. The graphical method can intuitively represent the distribution characteristics and variation rules of isotopes, while the MixSIAR model is based on Bayesian statistical theory and considers multi-water sources mixing, which improves the accuracy of calculating the contribution ratio of soil water to xylem water at different depths. In this study, the xylem water uptake depths of alfalfa under winter irrigation were identified by the graphical method and the MixSIAR model and were found to be consistent.

After freezing irrigation, alfalfa absorbed soil water only when the soil water content in the root layers were high enough; this is caused by high water volume freezing irrigation. Soil water in soil 
strata at depths of 0-10 cm, 10-20 cm, 20-30 cm, 30-40 cm, 40-50 cm, and 50-60 cm contributed 17.40\%, $9.55 \%, 9.00 \%, 11.75 \%, 32.05 \%$ and $20.20 \%$, respectively, to alfalfa xylem water. The soil layers with the highest contribution rates were $40-50 \mathrm{~cm}, 50-60 \mathrm{~cm}$, and 0-10 cm, from high to low, and their total contribution rate was $70 \%$. Low and medium water volume freezing irrigation only caused changes in the content of soil water, but alfalfa did not directly absorb soil water. Freezing irrigation improved the habitat conditions for alfalfa before overwintering, helped it enter the overwintering period healthy, and had a significant effect on increasing its overwintering rate.

From the third day after the thawing irrigation, alfalfa gradually began to absorb soil water. It showed different characteristics of water uptake under low, medium, and high water volume thawing irrigation. Middle and deep soil strata were the main layers at which alfalfa xylem water was absorbed under low water volume thawing irrigation conditions. Alfalfa absorbed soil water at different points and depths under medium and high water volume thawing irrigation conditions. The contribution rate of soil water to alfalfa water uptake under medium water volume thawing irrigation was similar at different soil layers and points, and the middle soil layers were the main water-absorbing layer after high water volume thawing irrigation. Thawing irrigation also alleviated environmental stress during the early stage at which alfalfa were revived and promoted the early regeneration of alfalfa. However, if the spring temperature varies greatly, alfalfa may suffer from late spring coldness if it was revived earlier. The optimum time for thawing irrigation should be considered according to the experience and meteorological conditions of that year to obtain the best effect.

Author Contributions: The research presented here was carried out in collaboration between all authors. Data curation, T.L.; Investigation, X.X. and S.M.; Project administration, J.W. and J.N.; Visualization, H.Z.; Writing-original draft, J.W.; Writing-review and editing, H.L. All authors have read and agreed to the published version of the manuscript.

Funding: We thank Jos van Dam of Wageningen University, assistant editor Evelyn Ning and two anonymous journal reviewers for their comments, which greatly improved this article. This research was funded by the research grants from Inner Mongolia Natural Science Foundation (Grant No. 2019MS05001), Research Project of China Institute of Water Resources and Hydropower Research (Grant No. MK2019J02), Special Fund of State Key Laboratory of Simulation and Regulation of Water Cycle in River Basin, China Institute of Water Resources and Hydropower Research (Grant No. SK2018ZY01, SK2018TS01) and the National Natural Science Foundation of China (Grant No. 51309165, 51579157, 51779156).

Conflicts of Interest: The authors declare no conflict of interest.

\section{References}

1. Kandelous, M.M.; Kamai, T.; Vrugt, J.A.; Šimůnek, J.; Hanson, B.; Hopmans, J.W. Evaluation of subsurface drip irrigation design and management parameters for alfalfa. Agric. Water Manag. 2012, 109, 81-93. [CrossRef]

2. Gu, J.; Yin, G.; Huang, P.; Guo, J.; Chen, L. An improved back propagation neural network prediction model for subsurface drip irrigation system. Comput. Electr. Eng. 2017, 60, 58-65. [CrossRef]

3. Lamm, F.R.; Trooien, T.P. Subsurface drip irrigation for corn production: A review of 10years of research in Kansas. Irrig. Sci. 2003, 22, 195-200. [CrossRef]

4. Yang, D.; Chen, F.; Zhou, Y. A Novel Eutrophication Assessment Models for Aquaculture Water Area via Artificial Neural Networks. J. Comput. Theor. Nanosci. 2015, 12, 2909-2912. [CrossRef]

5. Çolak, Y.B.; Yazar, A.; Çolak, İ.; Akça, H.; Duraktekin, G. Evaluation of Crop Water Stress Index (CWSI) for Eggplant under Varying Irrigation Regimes Using Surface and Subsurface Drip Systems. Agric. Agric. Sci. Procedia 2015, 4, 372-382. [CrossRef]

6. Patel, N.; Rajput, T.B.S. Effect of deficit irrigation on crop growth, yield and quality of onion in subsurface drip irrigation. Int. J. Plant Prod. 2013, 7, 417-436.

7. Rop, D.K.; Kipkorir, E.C.; Taragon, J.K. Effects of Deficit Irrigation on Yield and Quality of Onion Crop. J. Agric. Sci. Camb. 2016, 8, 112. [CrossRef]

8. Hongfu, Z. Alfalfa Science; China Agriculture Press: Beijing, China, 2009; pp. 121-125.

9. Shaojie, M.; Yongliang, Y.; Chao, Z.; Kexin, Z. Spatio-temporal patterns of precipitation-use efficiency of grassland in Northwestern China. Acta Ecol. Sin. 2017, 37, 1458-1471. [CrossRef] 
10. Wang, D.; He, C.; Wu, H.; You, Y.; Wang, G. Review of Alfalfa Full-mechanized Production Technology. Trans. Chin. Soc. Agric. Mach. 2017, 48, 1-25.

11. Ayars, J.E.; Fulton, A.; Taylor, B. Subsurface drip irrigation in California-Here to stay? Agric. Water Manag. 2015, 157, 39-47. [CrossRef]

12. Meinzer, F.C.; Clearwater, M.J.; Goldstein, G. Water transport in trees: Current perspectives, new insights and some controversies. Environ. Exp. Bot. 2001, 45, 239-262. [CrossRef]

13. Dawson, T.E. Hydraulic lift and water use by plants: Implications for water balance, performance and plant-plant interactions. Oecologia 1993, 95, 565-574. [CrossRef] [PubMed]

14. Ehleringer, J.R.; Dawson, T.E. Water uptake by plants: Perspectives from stable isotope composition. Plant Cell Environ. 1992, 15, 1073-1082. [CrossRef]

15. Picon-Cochard, C.; Nsourou-Obame, A.; Collet, C.; Guehl, J.M.; Ferhi, A. Competition for water between walnut seedlings (Juglans regia) and rye grass (Lolium perenne) assessed by carbon isotope discrimination and delta18O enrichment. Tree Physiol. 2001, 21, 183-191. [CrossRef] [PubMed]

16. Dawson, T.E.; Ehleringer, J.R. Streamside trees that do not use stream water. Nature 1991, 350, $335-337$. [CrossRef]

17. Ellsworth, P.Z.; Williams, D.G. Hydrogen isotope fractionation during water uptake by woody xerophytes. Plant Soil 2007, 291, 93-107. [CrossRef]

18. Thorburn, P.J.; Walker, G.R.; Brunel, J.P. Extraction of water from Eucalyptus trees for analysis of deuterium and oxygen-18: Laboratory and field techniques. Plant Cell Environ. 1993, 16, 269-277. [CrossRef]

19. Barbeta, A.; Jones, S.P.; Clavé, L.; Wingate, L.; Gimeno, T.E.; Fréjaville, B.; Wohl, S.; Ogée, J. Hydrogen isotope fractionation affects the identification and quantification of tree water sources in a riparian forest. Hydrol. Earth Syst. Sci. Discuss. 2018, 2018, 1-29. [CrossRef]

20. Evaristo, J.; Mcdonnell, J.J.; Clemens, J. Plant source water apportionment using stable isotopes: A comparison of simple linear, two-Compartment mixing model approaches. Hydrol. Process. 2017, 1-9. [CrossRef]

21. Du, X.L.; Wang, S.J. Recent Advances of Stable Hydrogen and Oxygen Isotopic Techniques in Plant Water Use Strategy. Chin. Agric. Sci. Bull. 2011, 27, 5-10.

22. Corbin, J.D.; Thomsen, M.A.; Dawson, T.E.; D'Antonio, C.M. Summer water use by California coastal prairie grasses: Fog, drought, and community composition. Oecologia 2005, 145, 511-521. [CrossRef] [PubMed]

23. Dawson, T.E.; Mambelli, S.; Plamboeck, A.H.; Templer, P.H.; Tu, K.P. Stable isotopes in plant ecology. Annu. Rev. Ecol. Syst. 2002, 33, 507-559. [CrossRef]

24. White, J.; Cook, E.; Lawrence, J.; Wallaces, B. The D/H ratios of sap in trees: Implications for water sources and tree ring D/H ratios. Geochim. Cosmochim. Acta 1985, 49, 237-246. [CrossRef]

25. Schulze, E.; Caldwell, M.M.; Canadell, J.; Mooney, H.A.; Jackson, R.B.; Parson, D.; Scholes, R.; Sala, O.E.; Trimborn, P. Downward flux of water through roots (i.e., inverse hydraulic lift) in dry Kalahari sands. Oecologia 1998, 115, 460-462. [CrossRef] [PubMed]

26. Querejeta, J.I.; Estrada-Medina, H.; Allen, M.F.; Jiménez-Osornio, J.J. Water source partitioning among trees growing on shallow karst soils in a seasonally dry tropical climate. Oecologia 2007, 152, 26-36. [CrossRef] [PubMed]

27. Rouillard, A.; Greenwood, P.F.; Grice, K.; Skrzypek, G.; Dogramaci, S.; Turney, C.; Grierson, P.F. Interpreting vegetation change in tropical arid ecosystems from sediment molecular fossils and their stable isotope compositions: A baseline study from the Pilbara region of northwest Australia. Palaeogeogr. Palaeoclimatol. Palaeoecol. 2016, 459, 495-507. [CrossRef]

28. Andriollo, D.D.; Redin, C.G.; Reichert, J.M.; Da Silva, L.S. Soil carbon isotope ratios in forest-grassland toposequences to identify vegetation changes in southern Brazilian grasslands. Catena 2017, 159, 126-135. [CrossRef]

29. Chimner, R.A.; Cooper, D.J. Using stable oxygen isotopes to quantify the water source used for transpiration by native shrubs in the San Luis Valley, Colorado U.S.A. Plant Soil 2004, 260, 225-236. [CrossRef]

30. Donovan, L.A.; Ehleringer, J.R. Water Stress and Use of Summer Precipitation in a Great Basin Shrub Community. Funct. Ecol. 1994, 8, 289. [CrossRef]

31. Rose, K.L.; Graham, R.C.; Parker, D.R. Water source utilization by Pinus jeffreyi and Arctostaphylos patula on thin soils over bedrock. Oecologia 2003, 134, 46-54. [CrossRef] 
32. Schifman, L.A.; Stella, J.C.; Volk, T.A.; Teece, M.A. Carbon isotope variation in shrub willow (Salix spp.) ring-wood as an indicator of long-term water status, growth and survival. Biomass Bioenergy 2012, 36, 316-326. [CrossRef]

33. Cheng, X.; An, S.; Li, B.; Chen, J.; Lin, G.; Liu, Y.; Luo, Y.; Liu, S. Summer rain pulse size and rainwater uptake by three dominant desert plants in a desertified grassland ecosystem in northwestern China. Plant Ecol. 2006, 184, 1-12. [CrossRef]

34. Guo, F.; Ma, J.; Zheng, L.; Sun, X.; Guo, X.; Zhang, X. Estimating distribution of water uptake with depth of winter wheat by hydrogen and oxygen stable isotopes under different irrigation depths. J. Integr. Agric. 2016, 15, 891-906. [CrossRef]

35. Oakes, A.M.; Hren, M.T. Temporal variations in the $\delta \mathrm{D}$ of leaf $\mathrm{n}$-alkanes from four riparian plant species. Org. Geochem. 2016, 97, 122-130. [CrossRef]

36. Polacik, K.A.; Maricle, B.R. Effects of flooding on photosynthesis and root respiration in saltcedar (Tamarix ramosissima), an invasive riparian shrub. Environ. Exp. Bot. 2013, 89, 19-27. [CrossRef]

37. Schwinning, S.; Starr, B.I.; Ehleringer, J.R. Summer and winter drought in a cold desert ecosystem (Colorado Plateau) part II: Effects on plant carbon assimilation and growth. J. Arid Environ. 2005, 61, 61-78. [CrossRef]

38. Yu, K.; D'Odorico, P. Climate, vegetation, and soil controls on hydraulic redistribution in shallow tree roots. Adv. Water Resour. 2014, 66, 70-80. [CrossRef]

39. Jidong, T.; Noriyuki, Y.; Sheng, Z.; Yi, H. Modelling water content redistribution during evaporation from sandy soil in the presence of water table. Comput. Geotech. 2016, 75, 210-224. [CrossRef]

40. Peñuelas, J.; Filella, I. Deuterium labelling of roots provides evidence of deep water access and hydraulic lift by Pinus nigra in a Mediterranean forest of NE Spain. Environ. Exp. Bot. 2003, 49, 201-208. [CrossRef]

41. Jiabin, W.; Shu, M.; Bing, X. Distribution of Stable Hydrogen and Oxygen Isotopes in the Root Zone of Alfalfa under Drip Irrigation. J. Irrig. Drain. 2017, 36, 14-17.

42. Naydenova, G.; Hristova, T.; Aleksiev, Y. Objectives and approaches in the breeding of perennial legumes for use in temporary pasturelands. Biotechnol. Anim. Husb. 2013, 29, 233-250. [CrossRef]

43. Sun, Q.; Wang, Y.; Hou, X. Alfalfa winter survival research summary. Pratacultural Sci. 2004, 21, $21-25$.

44. Keane, R.E.; Mahalovich, M.F.; Bollenbacher, B.L.; Manning, M.E.; Loehman, R.A.; Jain, T.B.; Holsinger, L.M.; Larson, A.J. Effects of Climate Change on Forest Vegetation in the Northern Rockies; Halofsky, J.E., Peterson, D.L., Eds.; Springer International Publishing: Cham, Switzerland, 2018; Volume 63, pp. 59-95.

45. Yu, H.; Liu, H.; Wang, J. Effects of cover and irrigation on winter surviving rate, soil temperature and soil moisture of algonquin alfalfa. Chin. J. Grassl. 2015, 37, 107-111.

46. Bingzhe, F.; Fugui, M.; Ruifang, L.; Duowen, S.; Xiangwei, H. Effect of covering soil and irrigation on overwintering rate and yield of Silphium perfoliatum L. Chin. J. Grassl. 2010, 32, 106-109.

47. Mikić, A.; Ćupina, B.; Rubiales, D.; Mihailović, V.; Šarūnaitè, L.; Fustec, J.; Antanasović, S.; Krstić, Đ.; Bedoussac, L.; Zorić, L.; et al. Models, Developments, and Perspectives of Mutual Legume Intercropping; Elsevier: Amsterdam, The Netherlands, 2015; Volume 130, pp. 337-419.

48. Demopoulos, A.W.J.; McClain-Counts, J.P.; Bourque, J.R.; Prouty, N.G.; Smith, B.J.; Brooke, S.; Ross, S.W.; Ruppel, C.D. Examination of Bathymodiolus childressi nutritional sources, isotopic niches, and food-web linkages at two seeps in the US Atlantic margin using stable isotope analysis and mixing models. Deep Sea Res. Part I Oceanogr. Res. Pap. 2019, 148, 53-66. [CrossRef]

49. Upadhayay, H.R.; Smith, H.G.; Griepentrog, M.; Bodé, S.; Bajracharya, R.M.; Blake, W.; Cornelis, W.; Boeckx, P. Community managed forests dominate the catchment sediment cascade in the mid-hills of Nepal: A compound-specific stable isotope analysis. Sci. Total Environ. 2018, 637-638, 306-317. [CrossRef]

50. Wu, H.; Zhao, G.; Li, X.; Wang, Y.; He, B.; Jiang, Z.; Zhang, S.; Sun, W. Identifying water sources used by alpine riparian plants in a restoration zone on the Qinghai-Tibet Plateau: Evidence from stable isotopes. Sci. Total Environ. 2019, 697, 134092. [CrossRef]

51. Wang, J.; Lu, N.; Fu, B. Inter-comparison of stable isotope mixing models for determining plant water source partitioning. Sci. Total Environ. 2019, 666, 685-693. [CrossRef]

52. Wan, S. Study on Alfalfa Production Performance and Its Ecological Effects on Soil Environment in the Loess Plateau. Ph.D. Thesis, Northwest A \& F University, Shaanxi, China, 2008. (In Chinese).

53. Xu, K.; Li, S. Physical and chemical properties of soil in alfalfa field for different cultivated years. Pratacult. Sci. 2015, 32, 1767-1773. (In Chinese) 
54. Zhao, R.; Zhang, B.; Wang, X.; Han, F. Ecological stoichiometry characteristics of soil and plant of alfalfa with different growing years on the Loess Plateau. Pratacult. Sci. 2019, 36, 1189-1199. (In Chinese)

55. Luo, Z.; Niu, Y.; Li, L.; Cai, L.; Zhang, R.; Xie, J. Soil moisture and alfalfa productivity response from different years of growth on the Loess Plateau of central Gansu. Acta Pratacult. Sci. 2015, 24, 31-38. (In Chinese)

56. You, Y.; Zhao, H.; Li, Y.; Wu, R.; Liu, G. Effects of cutting system on the forage yield and quality of alfalfa in Haihe Plain area. Chin. J. Grassl. 2018, 40, 47-55. (In Chinese)

57. Sulc, R.M.; Albrecht, K.A.; Palta, J.P.; Duke, S.H. Leakage of Intracellular Substances from Alfalfa Roots at Various Subfreezing Temperatures. Crop Sci. 1991, 31, 1575. [CrossRef]

58. Li, X.; Kang, Y. Agricultural utilization and vegetation establishment on saline-sodic soils using a water-salt regulation method for scheduled drip irrigation. Agric. Water Manag. 2020, 231, 105995. [CrossRef]

59. Zhang, Z.; Li, H.; Li, J.; Cheng, P.; Liu, B.; Li, C. Effects of different dripper discharges on soil water infiltration/redistribution under drip irrigation. Agric. Res. Arid Areas 2016, 34, 224-231. (In Chinese)

60. West, A.G.; Patrickson, S.J.; Ehleringer, J.R. Water extraction times for plant and soil materials used in stable isotope analysis. Rapid Commun. Mass Spectrom. 2010, 20, 1317-1321. [CrossRef] [PubMed]

61. West, A.G.; Goldsmith, G.R.; Brooks, P.D.; Dawson, T.E. Discrepancies between isotope ratio infrared spectroscopy and isotope ratio mass spectrometry for the stable isotope analysis of plant and soil waters. Rapid Commun. Mass Spectrom. RCM 2010, 24, 2687-2688. [CrossRef]

62. Yang, B.; Wen, X.; Sun, X. Seasonal variations in depth of water uptake for a subtropical coniferous plantation subjected to drought in an East Asian monsoon region. Agric. For. Meteorol. 2015, 201, 218-228. [CrossRef]

63. Wang, J.; Fu, B.; Lu, N.; Zhang, L. Seasonal variation in water uptake patterns of three plant species based on stable isotopes in the semi-arid Loess Plateau. Sci. Total Environ. 2017, 609, 27-37. [CrossRef]

64. Stock, B.C.; Semmens, B.X. Unifying error structures in commonly used biotracer mixing models. Ecology 2016, 97. [CrossRef]

65. Youri, R.; Mathieu, J. Reviews and syntheses: Isotopic approaches to quantify root water uptake: A review and comparison of methods. Biogeosciences 2017, 14, 2199-2224.

66. Eggemeyer, K.D.; Awada, T.; Harvey, F.E.; Wedin, D.A.; Zhou, X.; Zanner, C.W. Seasonal changes in depth of water uptake for encroaching trees Juniperus virginiana and Pinus ponderosa and two dominant C4 grasses in a semiarid grassland. Tree Physiol. 2009, 29, 157-169. [CrossRef] [PubMed]

67. Rozanski, K.; Araguás-Araguás, L.; Gonfiantini, R. Isotopic Patterns in Modern Global Precipitation. Clim. Chang. Cont. Isot. Rec. 1933, 78, 1-36.

68. Wu, Y.; Du, T.; Li, F.; Li, S.; Ding, R.; Tong, L. Quantification of maize water uptake from different layers and root zones under alternate furrow irrigation using stable oxygen isotope. Agric. Water Manag. 2016, 168, 35-44. [CrossRef]

69. English, N.B.; Dettman, D.L.; Sandquist, D.R.; Williams, D.G. Past climate changes and ecophysiological responses recorded in the isotope ratios of saguaro cactus spines. Oecologia 2007, 154, 247-258. [CrossRef]

70. Ma, Y.; Song, X. Seasonal Variations in Water Uptake Patterns of Winter Wheat under Different Irrigation and Fertilization Treatments. Water 2018, 10, 1633. [CrossRef]

71. Li, Y.; Su, D. Alfalfa Water Use and Yield under Different Sprinkler Irrigation Regimes in North Arid Regions of China. Sustainability 2017, 9, 1380. [CrossRef]

72. Guo, X.; Sun, X.; Ma, J.; Lei, T.; Zheng, L.; Wang, P. Simulation of the Water Dynamics and Root Water Uptake of Winter Wheat in Irrigation at Different Soil Depths. Water 2018, 10, 1033. [CrossRef]

73. Djaman, K.; O’Neill, M.; Owen, C.; Smeal, D.; West, M.; Begay, D.; Allen, S.; Koudahe, K.; Irmak, S.; Lombard, K. Long-Term Winter Wheat (Triticum aestivum L.) Seasonal Irrigation Amount, Evapotranspiration, Yield, and Water Productivity under Semiarid Climate. Agronomy 2018, 8, 96. [CrossRef]

74. Chen, S.; Sun, C.; Wu, W.; Sun, C. Water Leakage and Nitrate Leaching Characteristics in the Winter Wheat-Summer Maize Rotation System in the North China Plain under Different Irrigation and Fertilization Management Practices. Water 2017, 9, 141. [CrossRef]

(C) 2020 by the authors. Licensee MDPI, Basel, Switzerland. This article is an open access article distributed under the terms and conditions of the Creative Commons Attribution (CC BY) license (http://creativecommons.org/licenses/by/4.0/). 